\title{
Advances in the management of cutaneous squamous cell carcinoma
}

\author{
Sonal A. Parikh ${ }^{1}$, Vishal A. Patel ${ }^{1 *}$ and Desiree Ratner ${ }^{2 *}$
}

Addresses: ${ }^{1}$ Columbia University Department of Dermatology 161 Fort Washington Ave. 12 th Floor, New York, NY 10032 , USA; ${ }^{2}$ Mount Sinai Beth Israel Cancer Center West, 325 W. 15th street, New York, NY 10011, USA

*Corresponding authors: Vishal A. Patel (vap2109@cumc.columbia.edu); Desiree Ratner (dratner@chpnet.org)

Fl000Prime Reports 2014, 6:70 (doi:10.12703/P6-70)

All FI000Prime Reports articles are distributed under the terms of the Creative Commons Attribution-Non Commercial License (http://creativecommons.org/licenses/by-nc/3.0/legalcode), which permits non-commercial use, distribution, and reproduction in any medium, provided the original work is properly cited.

The electronic version of this article is the complete one and can be found at: http://f $1000 . c o m /$ prime/reports $/ \mathrm{m} / 6 / 70$

\begin{abstract}
Cutaneous squamous cell carcinoma is one of the most common non-melanoma skin cancers worldwide. While most cutaneous squamous cell carcinomas are easily managed, there is a high-risk subset of tumors that can cause severe morbidity and mortality. Tumor characteristics as well as patient characteristics contribute to the classification of cutaneous squamous cell carcinomas as low-risk vs. high-risk. Advances in the treatment of cutaneous squamous cell carcinomas largely relate to the management of this high-risk subset. Surgical and non-surgical management options, including newer targeted molecular therapies, will be discussed here. Larger, multicenter studies are needed to determine the exact significance of individual risk factors with respect to aggressive clinical behavior and the risks of metastasis and death, as well as the role of surgical and adjuvant therapies in patients with high-risk cutaneous squamous cell carcinomas.
\end{abstract}

\section{Introduction}

Cutaneous squamous cell carcinoma (CSCC) is the second most common non-melanoma skin cancer (NMSC) worldwide. While most of these lesions can be successfully managed with excision, there is a subset of lesions that metastasize, leading to severe morbidity and mortality. While small, the number of cSCCs that metastasize has been compared to the metastatic rate of renal and oropharyngeal carcinomas, as well as melanoma [1]. Given the relative ease of treating most cSCCs, most advances in treatment and the focus of our review relate to the management of the small but serious subset of high-risk cSCCs with metastatic potential.

\section{Identification of high-risk cSCC}

Given the variability of cSCC behavior, early identification of those cSCCs that are high-risk for recurrence and metastasis is important, so that appropriate management can be initiated. Significant literature has attempted to characterize high-risk features and their correlation with poor outcomes, but no consensus exists regarding how to define high-risk cSCC. The National Comprehensive
Cancer Network (NCCN) and the American Joint Committee on Cancer (AJCC) have distinct criteria to determine whether a lesion is high-risk, but no data supporting one definition over the other have been validated. As a result, classification of high-risk cancers is essentially up to the discretion of the clinician, taking into consideration the patient, the history, and the characteristics of the lesion. Factors that suggest that a lesion is more likely to demonstrate high-risk clinical behavior are discussed below.

\section{Tumor factors}

Multiple outcome studies have demonstrated that cSCCs with the following characteristics have a greater risk of metastasis: tumor recurrence, diameter greater than or equal to $2 \mathrm{~cm}$, location on the ear, vermilion lip, "mask areas" of the face, hands, feet, genitalia or in embryonic fusion planes, thickness greater than $2 \mathrm{~mm}$, poorly differentiated histology, or invasion of the subcutaneous tissue or structures such as perineural, vascular, or lymphatic tissue [1-6]. Recent evidence has shown that specifically named nerve involvement or involvement of 
nerves greater than $0.1 \mathrm{~mm}$ in diameter is specifically associated with a poor prognosis [3].

\section{Host factors \\ Immunosuppression}

It is well documented that immunosuppressed patients are at greater risk of developing CSCC than the general population. While cSCCs make up $20 \%$ and basal cell carcinomas make up $80 \%$ of NMSCs in immunocompetent patients, the statistics are reversed in the immunosuppressed population [7]. Patients who have undergone solid organ transplantation have a 65 to 250 -fold increased incidence of developing CSCC [8-10], and that risk positively correlates with higher doses of immunosuppression. These cancers are more aggressive, with an increased risk of local and distant metastases [11]. Recurrence and mortality rates are also higher in patients who are immunosuppressed (5\%) than those who are immunocompetent $(1 \%)[12,13]$. Heart transplant recipients are at the highest risk of developing aggressive or metastatic CSCC followed by renal, lung, and liver recipients [12]. Patients who suffer from hematologic malignancies and myelodysplastic syndromes are also at greater risk for developing CSCC, with chronic lymphocytic leukemia and small lymphocytic lymphoma associated with the highest risk $[12,14,15]$. Lastly, patients with autoimmune or chronic inflammatory disorders, such as inflammatory bowel disease and rheumatoid arthritis (on chronic immunosuppressants), as well as patients with HIV, are at greater risk of cSCC development [16-19].

\section{Chronic wounds}

In addition to chronically immunosuppressed patients, patients with a history of UV light or radiation therapy or those who suffer from chronic skin injuries, such as wounds, ulcers, or burns, are at increased risk of developing aggressive or metastatic cSCC [12, 20-23]. Included in this category are patients with a genetic predisposition to skin injury, many of whom suffer from genodermatoses, including epidermolysis bullosa, xeroderma pigmentosum, epidermodysplasia verruciformis, oculocutaneous albinism, and congenital dyskeratosis $[12,24]$.

We classify tumors as high-risk when they possess at least two or three high-risk features on initial evaluation. We also recommend defining a more specific category of very high-risk cSCC for tumors that demonstrate lymphovascular, perineural, periorbital, parotid, cartilaginous or bony invasion, or if they develop in-transit, regional, or distant metastasis [25].

\section{Work up}

Staging is the most critical step when determining the best way to treat high-risk cSCC. While the AJCC and the
International Union Against Cancer (UICC) have created staging systems based on expert consensus, neither one accurately determines prognosis. Validation and comparative studies of the AJCC and UICC staging systems executed by a group at Brigham and Women's Hospital (BWH) found that the bulk of poor outcomes (i.e. nodal metastasis, disease-specific death) occurred in the AJCC T2 tumors and that the T3 and T4 stages of the two systems were indistinct $[4,26]$. The group proposed an alternative staging system that divided the AJCC T2 stage into two groups (T2a and T2b) based on risk (Table 1) and were able to show that $72 \%$ of nodal metastases and $83 \%$ of diseasespecific deaths occurred in the T2b group. This alternative system, though not yet widely accepted and an area of developing knowledge, appears to more accurately correlate prognosis with staging as it relates to four risk factors, each of which is an independent prognostic predictor. These high-risk factors include diameter greater than or equal to $2 \mathrm{~cm}$, tumor invasion beyond fat, perineural invasion greater than or equal to $0.1 \mathrm{~mm}$, and poorly differentiated histology [4]. A study comparing the three staging systems demonstrated that the alternative staging system provides improved distinctiveness, homogeneity, and monotonicity compared to the AJCC and UICC staging systems [4].

CSCC has an estimated 3.7-5.4\% risk of nodal metastasis and an estimated disease-specific death rate of $1.5-2.1 \%$ [4]. Of those cSCCs that metastasize, $80 \%$ involve regional lymph nodes $[5,25,27]$. CSCCs can also metastasize to distant sites including the lungs, liver, brain, bones, and other cutaneous locations $[27,28]$. The risk factors most often associated with metastasis include perineural invasion, recurrence after treatment, size greater than $2 \mathrm{~cm}$, and poorly differentiated histology $[6,29]$.

Table I. Brigham and women's hospital alternative staging system [4]

\begin{tabular}{ll}
\hline Stage & Criteria \\
\hline TI & 0 high-risk factors \\
T2a & I high-risk factor \\
T2b & $2-3$ high-risk factors \\
T3 & $\geq 4$ high-risk factors OR bone \\
invasion \\
High-risk factors: & \\
- Tumor diameter $\geq 2 \mathrm{~cm}$ & \\
- Poorly differentiated histology & \\
- Perineural invasion $\geq 0.1 \mathrm{~mm}$ & \\
- Tumor invasion beyond fat (excludes & \\
bone invasion) & \\
\hline
\end{tabular}

\section{Radiologic imaging}

The role of radiologic imaging has not been established in the diagnosis or staging of cSCC. However, if involvement of lymph nodes is not clinically evident (but highly 
suspected) in lesions that possess features of very high-risk CSCC, radiologic imaging modalities [including ultrasound, computerised tomography (CT) scan, magnetic resonance imaging (MRI), and positron emission tomography (PET)/CT] may be considered in order to confirm negative lymph nodes and assist in preoperative planning $[30,31]$. A recent survey of surgeons using Mohs micrographic surgery (MMS) demonstrated that perineural invasion and in-transit metastasis were top factors in the consideration of obtaining nodal imaging [32]. In the few studies of imaging in cSCC that exist, the sensitivities and specificities of different imaging modalities are variable

[30]. Of the surgeons that participated in the study, 54\% preferred CT scan, 36\% MRI, and 15\% PET scan to evaluate their patients with high risk CSCC [31,32].

\section{Role of nodal biopsy}

Given that an estimated $80 \%$ of metastatic cSCCs involve lymph nodes, examining sentinel lymph nodes for early detection of metastasis in the hopes of reducing diseaserelated morbidity and mortality could be beneficial. A recent study to evaluate which stages of the AJCC and BWH alternative staging systems were associated with positive sentinel lymph node biopsy (SLNB) findings in non-anogenital CSCC found that positive SNLBs were more likely in T2 lesions of both staging systems, with a greater risk in lesions larger than $2 \mathrm{~cm}$ [27]. However, the rate of positive SNLB was statistically higher in $\mathrm{T} 2 \mathrm{~b}$ lesions than T2a lesions of the BWH system, suggesting that the BWH system appears more precise in delineating which high-risk lesions would warrant SNLB [27]. Other studies have shown excellent negative predictive values for SLNB for cSCCs ranging from 95.2 to $100 \%$ and suggest that SLNB may be of value to rule out nodal metastases [33]. Research continues to be conducted in order to validate the routine use of SLNB in CSCC but very high-risk patients may benefit from undergoing this procedure.

\section{Management \\ Surgical options}

Excisional surgery

Surgical excision is often the treatment of choice for cSCC, as it is an outpatient procedure, has shorter healing times, allows for histologic examination of tissue, and offers cure rates as high as 95\% for selected primary cSCC [34]. Typically, a margin of normal skin is removed at the time of tumor removal, which varies depending on the severity of the lesion, with a recommended 4-6 mm margin of normal skin for low-risk CSCC and 6-10 mm for high-risk cSCC $[6,35,36]$. Excised tissue specimens should be sent to a pathologist for careful margin examination to ensure complete tumor removal. Clear data are lacking regarding the appropriate margins of normal skin to remove for tumors with multiple high-risk features.
National guidelines require a minimum $10 \mathrm{~mm}$ margin of normal skin. We recommend considering wider margins of at least $15 \mathrm{~mm}$ for lesions with multiple high-risk characteristics or that are considered very highrisk, to ensure complete tumor clearance. Margins this wide, of course, are only feasible for limited areas of the body that have enough tissue laxity to accommodate such large defects. As a result, high-risk tumors should be treated by MMS instead of standard surgical excision to allow for confirmed removal of tumor without the need for prophylactically wide margins of normal skin.

\section{Mohs micrographic surgery}

MMS is a surgical technique that provides detailed microscopic visualization of the tissue removed for accurate identification of positive tumor margins, to provide a greater guarantee of complete tumor clearance. As surgical excision with negative margins is associated with significantly lower recurrence rates than those with unknown or positive margins, MMS is the gold standard for the surgical removal of high-risk cSCC $[37,38]$. MMS offers cure rates of $97 \%$ for primary cSCC and $94 \%$ for recurrent cSCCs [21,37]. Recent studies have shown that MMS is highly effective in treating high-risk cSCCs and preventing local recurrence $[39,40]$. Extensive tumors may warrant a multidisciplinary team to achieve complete clearance in the event of bony invasion, tracking along major nerves, parotid gland involvement, or in-transit metastasis.

\section{Nonsurgical options}

Radiation therapy

Given its non-invasive nature, radiation therapy has been used as a non-surgical primary treatment option for highrisk cSCC. It has a wide range of cure rates, with lower rates for aggressive cSCC types (Table 2). Radiation therapy has demonstrated outcomes comparable to surgery for tumors on the lip and eyelid [41,42]. It necessitates an intensive treatment schedule involving weeks of commitment and does not allow for histologic confirmation of tumor margins. Additionally, there are side effects of radiation therapy that some patients may not tolerate, including malaise, nausea, induced erythema, telangiectasia, or hypopigmentation, epidermal atrophy, soft-tissue necrosis, and radiation-induced malignancy [43]. Therefore, radiation therapy is probably best suited for patients

Table 2. Cure rates of CSCC with radiation therapy [45,66-69]

\begin{tabular}{ll}
\hline Tumor characteristic & $\begin{array}{l}\text { Cure rate with radiation } \\
\text { therapy }\end{array}$ \\
\hline Size $<1.0 \mathrm{~cm}$ low-risk, non-aggressive & $97.8 \%$ \\
Size $1.0-3.0 \mathrm{~cm}$ & $80-90 \%$ \\
Incidental perineural invasion & $80 \%$ \\
$>3.0 \mathrm{~cm}$ or recurrent tumors & $50-88 \%$ \\
Locally advanced & $55 \%$ \\
\hline
\end{tabular}


who are poor surgical candidates, who have tumors in locations that are inoperable, or whose reconstruction would cause cosmetic or functional drawbacks [43]. Otherwise, radiation therapy alone is used most frequently as salvage or palliative therapy in tumors that have failed to respond to other treatment options [44].

\section{Adjuvant therapy options}

Adjuvant treatment in the management of high-risk cSCC is advisable given the risk of recurrence, metastasis, and disease-specific death associated with it. While there are multiple possible options for therapy adjuvant to surgery, there is minimal consensus regarding the best perioperative management of high-risk CSCC [32].

\section{Adjuvant radiation therapy}

Adjuvant radiation therapy is used in areas with an increased likelihood of residual disease. Postoperative radiation therapy is typically indicated when tumor margins are positive, when there are multiple recurrences, and when there is perineural invasion, or involvement of the bones or nerves [45]. However, there is little consensus regarding which patients benefit from adjuvant radiation therapy, as the data available are limited [32]. We agree with the NCCN recommendations that adjuvant radiation therapy should be considered for patients with symptomatic perineural invasion of large-caliber nerves [6]. We also recommend adjuvant radiation for patients with uncertain tumor clearance or bone involvement.

\section{Targeted molecular therapies}

Increased expression of epidermal growth factor receptor (EGFR) in CSCC has been repeatedly noted to exert significant effects upon cellular proliferation, progression, and survival [46,47]. As a result, therapies aimed at inhibiting EGFR have been studied. These therapies consist of monoclonal antibodies such as cetuximab and panitumumab, or small molecule tyrosine kinase inhibitors such as erlotinib and gefitinib [48]. Cetuximab is a monoclonal antibody that binds to the extracellular component of the receptor, blocking EGFR and downstream signaling pathways that lead to cell proliferation and survival. The US Food and Drug Administration (FDA) approved cetuximab for treatment of head and neck SCC in 2006 [7]. Cetuximab has since been used in the treatment of advanced cSCC in an off-label fashion. There have been few clinical trials determining the role of cetuximab in cSCC treatment. One phase II prospective clinical trial examining 31 patients with surgically unresectable or metastatic cSCC showed that cetuximab was beneficial, with a $69 \%$ disease control rate and $28 \%$ response rate [49]. A study looking at cetuximab in an adjuvant role with surgery demonstrated improved outcomes in patients with very high-risk cSCC [25]. Patients who develop an acne-like rash with cetuximab treatment have better therapeutic responses with sustained progression-free survival [49]. Few case reports exist in the literature suggesting a positive role of panitumumab in CSCC $[48,50]$. A phase I study of erlotinib used with radiation therapy in patients with advanced CSCC was also conducted and suggested positive results [51].

Very recent studies have also looked at the role of $\$ 100$ proteins A8 and A9 in CSCC, suggesting a possible therapeutic role for these proteins normally found in neutrophils, monocytes, and macrophages [52]. Further, larger studies using these molecular therapies are required in order to establish a definitive role in the treatment of cSCC.

\section{Chemotherapy}

Chemotherapy is typically used in locally advanced or metastatic cSCC. Multiple chemotherapy agents have been used, including methotrexate, bleomycin, doxorubicin, and cisplatin, alone or in combination with 5-fluorouracil [53]. While there are no reports of the benefit of using chemotherapy as an adjuvant to surgery, chemoprophylaxis for the prevention of new cSCC with retinoids and capecitabine is useful, as discussed below.

\section{Special considerations in the management of high-risk patients \\ Field cancerization therapy}

Field cancerization in skin refers to a bed of genetically altered tissue secondary to carcinogenic insults, within which malignancies may be scattered [54]. In other words, a carcinogenic insult affects a large surface area, creating a bed of actinically damaged skin in which tumors may be present or develop. In these circumstances, surgeons must be careful to excise only biopsy-proven cancerous lesions to avoid removing excess tissue. Once these have been addressed, attention must also be directed at treating the larger surface of actinically-damaged skin.

Multiple modalities exist to address actinically damaged skin in patients with field cancerization. Medications including 5-fluorouracil 5\%, imiquimod 5\%, diclofenac $3 \%$, chemical peels, and ingenol mebutate are effective at treating large areas of actinic damage with only topical applications [55]. Photodynamic therapy, a modality that utilizes a photosensitizer such as methyl aminolevulinate (MAL) or aminolevulinic acid (ALA), a light source, and reactive oxygen species, has been used to treat and prevent actinic damage as well. Multiple studies have demonstrated the utility of photodynamic therapy in field cancerization [56]. We recommend using photodynamic therapy in conjunction with topical regimens in order to maximize clearance. We recommend two cycles 
of photodynamic therapy two weeks apart followed by a 6 to 8 week holiday. Photodynamic therapy every 4 to 8 weeks has also been demonstrated as an effective preventive measure in patients with field cancerization who are immunosuppressed [57].

Oral therapies with retinoids and capecitabine have also been used for field cancerization therapy. Oral retinoids have been shown to reduce the incidence and burden of actinic keratosis and CSCC $[58,59]$. Although there are no guidelines, experts recommend the use of oral retinoids for chemoprevention in patients with innumerable actinic keratoses, numerous (5-10) NMSCs yearly, NMSCs that develop at an accelerated frequency, multiple NMSCs in high-risk areas, eruptive keratoacanthomas, and high-risk or metastatic NMSC [60]. While both isotretinoin and acitretin are effective chemopreventive agents, we recommend acitretin due to its lower cost, ease of prescribing, and literature support of its use in high-risk and organ transplant patients [58]. Patients who are prescribed oral retinoids should receive baseline evaluations of complete blood counts, basic metabolic and lipid panels as well as liver function tests, with monthly follow-up of mucocutaneous side effects, liver function tests, creatinine levels, and a lipid panel [60].

Capecitabine, an oral precursor of 5-fluorouracil, has been used as chemoprophylaxis in patients with diffuse field cancerization, though it is recommended for use only after patients have failed to respond to oral retinoids, given its more significant adverse event profile [61-63]. A study involving organ transplant patients demonstrated that capecitabine was associated with a 0.33 and 2.45 decrease in event occurrence rates of cSCC and actinic keratosis per month, respectively [64]. Before initiating treatment, patients should be evaluated for any dihydropyrimidine dehydrogenase deficiencies, as the enzyme plays a critical role in 5-fluorouracil metabolism [65].

\section{Follow up}

The NCCN recommendations for follow up of patients with high-risk cSCC are detailed in Table 3. Patients with high-risk cSCC have a greater risk of developing recurrence, lymph node or distant metastasis, or another highrisk tumor [28]. Of the lesions at risk, 70-80\% will locally recur or metastasize within the first 2 years and 95\% within the first 5 years of the initial cSCC diagnosis [21]. Between 30 and $50 \%$ of patients will develop a second skin cancer within 5 years [53]. Thus, close follow up is critical. A multidisciplinary team approach involving cutaneous, medical and radiation oncologists, Mohs and oncologic surgeons, and dermatopathologists should be considered for very high-risk patients to optimize follow up and disease-free survival.
Table 3. The National Comprehensive Cancer Network (NCCN) recommendations for patient follow up [6]

\begin{tabular}{ll}
\hline Patient & Follow up \\
\hline High-risk cSCC & - Full skin exam and lymph node exam \\
& every 3-6 months for first 2 years \\
& - Every 6-12 months for next 3 years \\
& - Annually after 5 years \\
High-risk cSCC with & - Full skin exam and lymph node exam \\
regional disease & every I-3 months for first year \\
& - Every 2-4 months for the next year \\
& - Every $4-6$ months until the fifth year \\
& - Every 6-12 months for patient's lifetime
\end{tabular}

\section{Conclusion}

Management of high-risk cSCC is complex, and a multidisciplinary approach is often required for this serious problem. Lack of large outcome studies assessing risk factors have left significant holes in the stratification and prognosis of disease, thus leading to inconsistent definitions and treatment recommendations. Precise tumor staging and clear risk stratification are needed for effective management of patients with cSCC. We have attempted to present a comprehensive and current expert opinion on high-risk cSCC management options. There is an as yet unmet need for larger, longitudinal multicenter studies to best determine the role of each risk factor, the risks of metastasis and death, and the effectiveness of surgical treatment and adjuvant therapies in patients with highrisk cSCC.

\section{Abbreviations}

AJCC, American Joint Committee on Cancer; BWH, Brigham and Women's Hospital; cSCC, cutaneous squamous cell carcinoma; CT, computerised tomography; EGFR, epidermal growth factor receptor; MRI, magnetic resonance imaging; MMS, Mohs micrographic surgery; NCCN, National Comprehensive Cancer Network; NMSC, non-melanoma skin cancer; PET, positron emission tomography; SNLB, sentinel lymph node biopsy; UICC, International Union Against Cancer.

\section{Disclosures}

The authors declare that they have no disclosures.

\section{References}

I. Karia PS, Han J, Schmults CD: Cutaneous squamous cell carcinoma: estimated incidence of disease, nodal metastasis, and deaths from disease in the United States, 20I2. J Am Acad Dermatol 2013, 68:957-66.

\section{FlOOOPrime} RECOMMENDED

2. Clayman GL, Lee JJ, Holsinger FC, Zhou X, Duvic M, El-Naggar AK, Prieto VG, Altamirano E, Tucker SL, Strom SS, Kripke ML, 
Lippman SM: Mortality risk from squamous cell skin cancer. J Clin Oncol 2005, 23:759-65.

3. Ross AS, Whalen FM, Elenitsas R, Xu X, Troxel AB, Schmults CD: Diameter of involved nerves predicts outcomes in cutaneous squamous cell carcinoma with perineural invasion: an investigator-blinded retrospective cohort study. Dermatol Surg 2009, 35:1859-66.

\section{FlOOOPrime}

\section{RECOMMENDED}

4. Karia PS, Jambusaria-Pahlajani A, Harrington DP, Murphy GF, Qureshi AA, Schmults CD: Evaluation of American Joint Committee on Cancer, International Union Against Cancer, and Brigham and Women's Hospital tumor staging for cutaneous squamous cell carcinoma. J Clin Oncol 2014, 32:327-34.

\section{FIOOOPrime}

5. Dinehart SM, Pollack SV: Metastases from squamous cell carcinoma of the skin and lip. An analysis of twenty-seven cases. J Am Acad Dermatol 1989, 21:24I-8.

6. Miller SJ: Defining, treating, and studying very high-risk cutaneous squamous cell carcinomas. Arch Dermatol 2010, I46: I 292-5.

7. Liu LS, Colegio OR: Molecularly targeted therapies for nonmelanoma skin cancers. Int J Dermatol 20I3, 52:654-65.

8. Berg D, Otley CC: Skin cancer in organ transplant recipients: Epidemiology, pathogenesis, and management. I Am Acad Dermatol 2002, 47:I-I7; quiz 18-20.

9. Herman S, Rogers HD, Ratner D: Immunosuppression and squamous cell carcinoma: a focus on solid organ transplant recipients. Skinmed 2007, 6:234-8.

10. Brantsch KD, Meisner C, Schönfisch B, Trilling B, Wehner-Caroli J, Röcken $M$, Breuninger $\mathrm{H}$ : Analysis of risk factors determining prognosis of cutaneous squamous-cell carcinoma: a prospective study. Lancet Oncol 2008, 9:7I3-20.

II. Smith KJ, Hamza S, Skelton H: Histologic features in primary cutaneous squamous cell carcinomas in immunocompromised patients focusing on organ transplant patients. Dermatol Surg 2004, 30:634-41.

\section{FlOOOPrime}

RECOMMENDED

12. Martorell-Calatayud A, Sanmartín Jimenez O, Cruz Mojarrieta J, Guillén Barona C: Cutaneous squamous cell carcinoma: defining the high-risk variant. Actas Dermosifiliogr 2013, 104:367-79.

13. Martinez J, Otley CC, Stasko T, Euvrard S, Brown C, Schanbacher CF, Weaver AL: Defining the clinical course of metastatic skin cancer in organ transplant recipients: a multicenter collaborative study. Arch Dermatol 2003, 139:301-6.

\section{FlOOOPrime \\ RECOMMENDED}

14. Frierson HF, Deutsch BD, Levine PA: Clinicopathologic features of cutaneous squamous cell carcinomas of the head and neck in patients with chronic lymphocytic leukemia/small lymphocytic lymphoma. Hum Pathol 1988, I 9: I397-402.

I5. Baskaynak G, Kreuzer K, Schwarz M, Zuber J, Audring H, Riess H, Dörken B, Le Coutre P: Squamous cutaneous epithelial cell carcinoma in two CML patients with progressive disease under imatinib treatment. Eur J Haematol 2003, 70:23 I-4.

16. De Luca, Jacqueline F, Severino R, Lee YS, Johnson D: Dermatologist and gastroenterologist awareness of the potential of immunosuppressants used to treat inflammatory bowel disease to cause non-melanoma skin cancer. Int J Dermatol 2013, 52:955-9.

17. van den Reek, JMPA, van Lümig, PPM, Janssen $M$, Schers $H$ J, Hendriks, JCM, van de Kerkhof, PCM, Seyger, MMB, de Jong, EMG]: Increased incidence of squamous cell carcinoma of the skin after long-term treatment with azathioprine in patients with auto-immune inflammatory rheumatic diseases. I Eur Acad Dermatol Venereol 2014, 28:27-33.

\section{FIOOOPrime
RECOMMENDED}

18. Silverberg MJ, Leyden W, Warton EM, Quesenberry CP, Engels EA, Asgari MM: HIV infection status, immunodeficiency, and the incidence of non-melanoma skin cancer. J Natl Cancer Inst 2013, 105:350-60.

\section{FlOOOPrime}

\section{RECOMMENDED}

19. Hausauer AK, Maurer T, Leslie KS, Parvataneni R, Stuart SE, Chren M Recurrence after treatment of cutaneous basal cell and squamous cell carcinomas in patients infected with human immunodeficiency virus. JAMA Dermatol 20I3, I49:239-4I.

20. Mullen JT, Feng L, Xing Y, Mansfield PF, Gershenwald JE, Lee JE, Ross MI, Cormier JN: Invasive squamous cell carcinoma of the skin: defining a high-risk group. Ann Surg Oncol 2006, I3:902-9.

\section{FlOOOPrime
RECOMMENDED}

21. Rowe DE, Carroll RJ, Day CL: Prognostic factors for local recurrence, metastasis, and survival rates in squamous cell carcinoma of the skin, ear, and lip. Implications for treatment modality selection. J Am Acad Dermatol 1992, 26:976-90.

22. Enoch S, Miller DR, Price PE, Harding KG: Early diagnosis is vital in the management of squamous cell carcinomas associated with chronic non healing ulcers: a case series and review of the literature. Int Wound J 2004, I:I65-75.

23. Lyakhovitsky A, Barzilai A, Fogel M, Trau H, Huszar M: Expression of e-cadherin and beta-catenin in cutaneous squamous cell carcinoma and its precursors. Am J Dermatopathol 2004, 26:372-8.

24. Fine J, Johnson LB, Weiner M, Li K, Suchindran C: Epidermolysis bullosa and the risk of life-threatening cancers: the National EB Registry experience, 1986-2006. J Am Acad Dermatol 2009, 60:203-II.

25. O'Bryan K, Sherman W, Niedt GW, Taback B, Manolidis S, Wang A, Ratner D: An evolving paradigm for the workup and management of high-risk cutaneous squamous cell carcinoma. J Am Acad Dermatol 2013, 69:595-602.el.

26. Jambusaria-Pahlajani A, Kanetsky PA, Karia PS, Hwang W, Gelfand JM, Whalen FM, Elenitsas R, Xu X, Schmults CD: Evaluation of AJCC tumor staging for cutaneous squamous cell carcinoma and a proposed alternative tumor staging system. JAMA Dermatol 2013, 149:402-10.

\section{FIOOOPrime}

27. Schmitt AR, Brewer JD, Bordeaux JS, Baum CL: Staging for cutaneous squamous cell carcinoma as a predictor of sentinel lymph node biopsy results: meta-analysis of American Joint Committee on Cancer criteria and a proposed alternative system. JAMA Dermatol 20|4, I50:19-24.

\section{FlOOOPrime \\ RECOMMENDED}

28. Johnson TM, Rowe DE, Nelson BR, Swanson NA: Squamous cell carcinoma of the skin (excluding lip and oral mucosa). J Am Acad Dermatol 1992, 26:467-84.

\section{FlOOOPrime \\ RECOMMENDED}

29. Moore BA, Weber RS, Prieto V, El-Naggar A, Holsinger FC, Zhou X Lee JJ, Lippman S, Clayman GL: Lymph node metastases from cutaneous squamous cell carcinoma of the head and neck. Laryngoscope 2005, I I5:I56I-7.

30. Yoon DY, Hwang HS, Chang SK, Rho Y, Ahn HY, Kim JH, Lee IJ: CT, MR, US, I8F-FDG PET/CT, and their combined use for the assessment of cervical lymph node metastases in squamous cell carcinoma of the head and neck. Eur Radiol 2009, 19:634-42.

31. Jennings L, Schmults CD: Management of high-risk cutaneous squamous cell carcinoma. J Clin Aesthet Dermatol 2010, 3:39-48. 
32. Jambusaria-Pahlajani A, Hess SD, Katz KA, Berg D, Schmults CD: Uncertainty in the perioperative management of high-risk cutaneous squamous cell carcinoma among Mohs surgeons. Arch Dermatol 2010, 146:|225-31.

\section{FlOOOPRime
RECOMMENDED}

33. Kwon S, Dong ZM, Wu PC: Sentinel lymph node biopsy for highrisk cutaneous squamous cell carcinoma: clinical experience and review of literature. World J Surg Oncol 20II, 9:80.

\section{FlOOOPRime
RECOMMENDED}

34. Swanson NA: Mohs surgery. Technique, indications, applications, and the future. Arch Dermatol 1983, 1 19:761-73.

35. Brodland DG, Zitelli JA: Surgical margins for excision of primary cutaneous squamous cell carcinoma. J Am Acad Dermatol 1992, 27:24I-8.

36. Sober A: Cutaneous SCC and other cutaneous carcinomas. In In AJCC Cancer Staging Manual. 7th edition. Edited by Edge SB et al. New York: Springer; 2010.

37. Leibovitch I, Huilgol SC, Selva D, Hill D, Richards S, Paver R: Cutaneous squamous cell carcinoma treated with Mohs micrographic surgery in Australia I. Experience over 10 years. J Am Acad Dermatol 2005, 53:253-60.

\section{FlOOOPrime} RECOMMENDED

38. Jambusaria-Pahlajani A, Miller CJ, Quon $H$, Smith $N$, Klein RQ, Schmults CD: Surgical monotherapy versus surgery plus adjuvant radiotherapy in high-risk cutaneous squamous cell carcinoma: a systematic review of outcomes. Dermatol Surg 2009, 35:574-85.

\section{FlOOOPrime}

\section{RECOMMENDED}

39. Belkin D, Carucci JA: Mohs surgery for squamous cell carcinoma. Dermatol Clin 201I, 29:161-74, vii.

40. Pugliano-Mauro M, Goldman G: Mohs surgery is effective for high-risk cutaneous squamous cell carcinoma. Dermatol Surg 2010, 36:1544-53.

4I. Veness MJ, Ong C, Cakir B, Morgan G: Squamous cell carcinoma of the lip. Patterns of relapse and outcome: Reporting the Westmead Hospital experience, 1980-1997. Australas Radiol 200I, 45: 195-9.

\section{FlOOOPrime}

\section{RECOMMENDED}

42. Caccialanza M, Piccinno R, Gaiani F, Contini D: Relevance of dermatologic radiotherapy in the therapeutic strategy of skin epithelial neoplasms: excellent results in the treatment of lesions localized on eyelids and skin overlying the cartilage of the nose. G Ital Dermatol Venereol 2013, I 48:83-8.

\section{FIOOOPrime}

43. Veness $M$, Richards S: Role of modern radiotherapy in treating skin cancer. Australas J Dermatol 2003, 44:159-66; quiz 167-8.

44. Al-Othman MO, Mendenhall WM, Amdur RJ: Radiotherapy alone for clinical T4 skin carcinoma of the head and neck with surgery reserved for salvage. Am J Otolaryngol 200I, 22:387-90.

\section{FlOOOPrime \\ RECOMMENDED}

45. Mendenhall WM, Amdur RJ, Hinerman RW, Cognetta $A B$, Mendenhall NP: Radiotherapy for cutaneous squamous and basal cell carcinomas of the head and neck. Laryngoscope 2009, I 19:1994-9.

46. Shimizu $T$, Izumi $H$, Oga A, Furumoto $H$, Murakami $T$, Ofuji $R$, Muto M, Sasaki K: Epidermal growth factor receptor overexpression and genetic aberrations in metastatic squamouscell carcinoma of the skin. Dermatology (Basel) 200I, 202:203-6.
47. Uribe P, Gonzalez S: Epidermal growth factor receptor (EGFR) and squamous cell carcinoma of the skin: molecular bases for EGFR-targeted therapy. Pathol Res Pract 20II, 207:337-42.

\section{FlOOOPrime RECOMMENDED}

48. Gaffney DC, Soyer HP, Simpson F: The epidermal growth factor receptor in squamous cell carcinoma: An emerging drug target. Australas J Dermatol 2014, 55:24-34.

\section{FlOOOPrime \\ RECOMMENDED}

49. Maubec E, Petrow P, Scheer-Senyarich I, Duvillard P, Lacroix L Gelly J, Certain A, Duval X, Crickx B, Buffard V, Basset-Seguin N, Saez P, Duval-Modeste A, Adamski H, Mansard S, Grange F, Dompmartin A, Faivre S, Mentré F, Avril M: Phase II study of cetuximab as first-line single-drug therapy in patients with unresectable squamous cell carcinoma of the skin. I Clin Oncol 20II, 29:3419-26.

\section{FlOOOPrime}

50. Eder J, Simonitsch-Klupp I, Trautinger F: Treatment of unresectable squamous cell carcinoma of the skin with epidermal growth factor receptor antibodies-a case series. Eur J Dermatol 2013, 23:658-62

5I. Heath CH, Deep NL, Nabell L, Carroll WR, Desmond R, Clemons L, Spencer S, Magnuson JS, Rosenthal EL: Phase I study of erlotinib plus radiation therapy in patients with advanced cutaneous squamous cell carcinoma. Int J Radiat Oncol Biol Phys 2013, 85:I275-8I.

52. Choi D, Li ZJ, Chang I, Yeo M, Kim J, Sohn K, Im M, Seo Y, Lee J, Kim C, Lee Y: Clinicopathological roles of SI00A8 and SI 00A9 in cutaneous squamous cell carcinoma in vivo and in vitro. Arch Dermatol Res 2014.

53. LeBoeuf NR, Schmults CD: Update on the management of highrisk squamous cell carcinoma. Semin Cutan Med Surg 20II, 30:26-34.

54. Torezan, Luís Antônio Ribeiro, Festa-Neto C: Cutaneous field cancerization: clinical, histopathological and therapeutic aspects. An Bras Dermatol 20I3, 88:775-86.

55. Lebwohl M, Swanson N, Anderson LL, Melgaard A, Xu Z, Berman B: Ingenol mebutate gel for actinic keratosis. N Engl J Med 20I2, 366:1010-9.

\section{FlOOOPrime}

\section{RECOMMENDED}

56. Gupta AK, Paquet M, Villanueva E, Brintnell W: Interventions for actinic keratoses. Cochrane Database Syst Rev 2012, 12:CD0044I5.

\section{FlOOOPrime} RECOMMENDED

57. Willey A, Mehta S, Lee PK: Reduction in the incidence of squamous cell carcinoma in solid organ transplant recipients treated with cyclic photodynamic therapy. Dermatol Surg 2010, 36:652-8.

58. Bavinck JN, Tieben LM, Van der Woude, FJ, Tegzess AM, Hermans J, ter Schegget J, Vermeer BJ: Prevention of skin cancer and reduction of keratotic skin lesions during acitretin therapy in renal transplant recipients: a double-blind, placebo-controlled study. J Clin Oncol 1995, 13:1933-8.

59. Wright TI, Spencer JM, Flowers FP: Chemoprevention of nonmelanoma skin cancer. J Am Acad Dermatol 2006, 54:933-46; quiz 947-50.

60. Otley CC, Stasko T, Tope WD, Lebwohl M: Chemoprevention of nonmelanoma skin cancer with systemic retinoids: practical dosing and management of adverse effects. Dermatol Surg 2006, 32:562-8.

6I. Endrizzi BT, Lee PK: Management of carcinoma of the skin in solid organ transplant recipients with oral capecitabine. Dermatol Surg 2009, 35:1567-72.

62. Zwald FO, Brown M: Skin cancer in solid organ transplant recipients: advances in therapy and management: part II. 
Management of skin cancer in solid organ transplant recipients. J Am Acad Dermatol 201 I, 65:263-79; quiz 280.

\section{FlOOOPrime}

63. Endrizzi B, Ahmed RL, Ray T, Dudek A, Lee P: Capecitabine to reduce nonmelanoma skin carcinoma burden in solid organ transplant recipients. Dermatol Surg 20I3, 39:634-45.

64. Jirakulaporn T, Endrizzi B, Lindgren B, Mathew J, Lee PK, Dudek AZ: Capecitabine for skin cancer prevention in solid organ transplant recipients. Clin Transplant 20II, 25:54I-8.

65. Bangash HK, Colegio OR: Management of non-melanoma skin cancer in immunocompromised solid organ transplant recipients. Curr Treat Options Oncol 2012, 13:354-76.
66. Scholten AN, Griep C, Davelaar J, Chin A, Leer JW: Elektronenbestraling effectief bij de behandeling van huidcarcinomen; een vergelijking met röntgencontacttherapie. Ned Tijdschr Geneeskd 1996, I40:428-31.

67. Locke J, Karimpour S, Young G, Lockett MA, Perez CA: Radiotherapy for epithelial skin cancer. Int J Radiat Oncol Biol Phys 200I, 5 I:748-55.

68. Lovett RD, Perez CA, Shapiro SJ, Garcia DM: External irradiation of epithelial skin cancer. Int J Radiat Oncol Biol Phys 1990, 19:235-42.

69. Kwan W, Wilson D, Moravan V: Radiotherapy for locally advanced basal cell and squamous cell carcinomas of the skin. Int J Radiat Oncol Biol Phys 2004, 60:406-II. 